\title{
Transfer of Land Use Rights in Rural China and Farmers' Utility: How to Select an Optimal Payment Mode of Land Increment Income
}

\author{
Lei Yan ${ }^{1}$, Kairong Hong ${ }^{1, *}$ and Hui Li $^{2}$ \\ 1 School of Business, Central South University, Changsha 410083, China; yanlei36@csu.edu.cn \\ 2 School of Economics, Central South University of Forestry and Technology, Changsha 410083, China; \\ t20172336@csuft.edu.cn \\ * Correspondence: hongkairong@csu.edu.cn; Tel.: +138-7310-8136
}

Citation: Yan, L.; Hong, K.; Li, H. Transfer of Land Use Rights in Rural China and Farmers' Utility: How to Select an Optimal Payment Mode of Land Increment Income. Land 2021, 10, 450. https://doi.org/10.3390/ land 10050450

Academic Editor: Carlos Parra-López

Received: 18 March 2021

Accepted: 21 April 2021

Published: 23 April 2021

Publisher's Note: MDPI stays neutral with regard to jurisdictional claims in published maps and institutional affiliations.

Copyright: (c) 2021 by the authors. Licensee MDPI, Basel, Switzerland. This article is an open access article distributed under the terms and conditions of the Creative Commons Attribution (CC BY) license (https:// creativecommons.org/licenses/by/ $4.0 /)$.

\begin{abstract}
Background: The distribution of farmers' increment income is the key to the transfer of land use rights. This research aims to detect the optimal payment mode for the distribution of land increment income obtained by farmers in land rights transfer. Methods: The research relied on case analysis, mathematical analysis, and numerical simulation. Results: According to China's existing payment modes for the increment income of rural collectively owned operating construction land (RCOCL), we summarized these payment modes into three: namely, lump-sum currency payment, a mixed payment of pension and lump-sum currency, and a mixed payment of dividend and lump-sum currency. If the land transfer price of RCOCL is lower than a specific value, the lump-sum currency payment will be optimal for farmers. Suppose the land transfer price is higher than this value. If the enterprise's profit margin is higher than the pension rate of return, the mixed payment of dividend and lump-sum currency will be optimal; if not, the mixed payment of pension and lump-sum currency will be optimal. Conclusions: Differences in regions, enterprise attributes, and farmers' characteristics will make the optimal proportion of pension or stock capital in land increment income (OPPSC) different. Generally, OPPSC is often between $40 \%$ and $60 \%$.
\end{abstract}

Keywords: payment mode; land institution reform; unified urban-rural land market; land increment income; farmers' utility; China

\section{Introduction}

China's long-term urban-oriented development strategy has led to the contradiction between land division, man-land separation, urban-rural division, and the unsatisfactory development of urban-rural integration. It has also given birth to the rural "rural diseases" such as such as increasingly desolate rural construction land, serious pollution of the rural water and soil environment, and multidimensional impoverishment of rural areas. The land system is the basic arrangement for rural development and the most important driving force for development [1]. However, in China, land in urban areas is owned by the state, and land in rural and suburban areas is collectively owned by farmers [2]. Any organization or individual who needs to use land for construction must apply for the use of state-owned land following the law. Rural collectively owned land can only be traded in the market after being expropriated as state-owned land by the local government $[3,4]$. However, part of the land increment income from transactions is paid to the farmers as compensation for land acquisition, and most of it is used as fiscal revenue used for urban construction by the local government [5]. Therefore, on the one hand, China's long-standing urban-rural dual land system has actively promoted China's urbanization development; on the other hand, it has also widened the urban-rural development gap [6-8].

In order to narrow the urban-rural development gap and promote the development of urban-rural integration, China is committed to establishing a unified urban and rural 
land transaction market and gradually allowing the transfer of rural land use rights on the basis of retaining ownership as a collective [9]. Since the 1980s, China has gradually practiced and regulated the transfer of rural agricultural land use rights. However, until 2014, the construction land use right in rural China was not allowed to be transferred. In 2014, China introduced the pilot reform of entering the market for rural collectively owned operating construction land (RCOCL) and began to explore the transfer of the construction land use rights in rural China for the first time. On the basis of the pilot reform of RCOCL, the new Land Management Law implemented in 2020 further allows RCOCL to enter the market throughout China. This means that the transfer of China's rural construction land use rights is officially guaranteed by law.

However, China's RCOCL entering the market is still in the exploratory stage, and some measures have yet to be improved. The conditions, scope, rules, and supervision measures of RCOCL entering the market need to be clarified, and its income distribution mechanism also needs to be improved [10]. Among them, improving the distribution mechanism of land increment income in the process of RCOCL entering the market is also the key to building a unified urban and rural construction land market, encouraging farmers and village collectives to actively participate in the marketization of RCOCL, so as to increase farmers' income and promote rural development [11]. If the distribution mechanism is reasonable, which can effectively stimulate the endogenous motivation of the farmer and village collective, it will realize a balanced share of the value of land development rights. If not, it will result in insufficient motivation for farmers and village collectives, which will hinder the entry of RCOCL into the market, fail to effectively deactivate the rural land element market, or even fail to build a unified urban and rural construction land market [11,12].

The increment income distribution of RCOCL entering the market includes two main aspects. One is the income distribution ratio among the participants-that is, farmers, the village collective, and the local government; the other is the question of which payment mode should be used for the increment income given to farmers. Regarding the income distribution ratio of RCOCL entering the market, the central government of China pointed out that the overall requirements for income distribution are to establish a land increment income distribution mechanism that takes into account the state, collectives, and individuals, and to protect farmers' land rights and ensure that farmers share the land increment benefits fairly [13]. The Ministry of Finance and the Ministry of Land and Resources of China stipulated that local governments shall collect $20 \%$ to $50 \%$ of the land increment income as an adjustment fee in the process of RCOCL entering the market [14]. Regarding the income distribution ratio between the village collective and farmers, only principled requirements were put forward as it belongs to the category of collective internal autonomy. Some scholars have also studied the optimal distribution ratio of the increment income of RCOCL entering the market based on the principal-agent theory, the maximization of the interests of the participants, and land use efficiency, which provide a reference for the increment income distribution of RCOCL [15-17].

The research on payment mode is mainly concentrated in the context of land acquisition and land fallowing in ecosystem services program. In land acquisition, researchers found that when the compensation plan includes shareholding, villagers are more willing to choose cooperation. This is because sharing dividends can ensure that farmers enjoy long-term land appreciation benefits [18-20]; in land fallowing, scholars conducted research in the context of the policies of the US, the EU, Japan, Germany, and Ireland, and they found that only compensation through prices cannot effectively motivate farmers [21,22]. Economic incentives have little effect on farmers' willingness to participate. Compensation methods should be more diversified, and differences in land use need to be considered [23-25]. However, what is the optimal payment mode for the compensation obtained by farmers? How to determine the optimal proportion of currency, social security, and shareholding in the compensation? To solve these problems, this paper takes the 
marketization of RCOCL as the policy background and discusses the optimal payment mode for land increment income based on the maximization of farmers' lifetime utility.

This research aims to detect the optimal payment mode for the land increment income obtained by farmers in the process of land rights transfer, which provides a reference for the formulation of payment plans for land rights transfer or ecosystem services programs. This paper is presented in four sections: Section 1 presents the theoretical framework on which the research is based. Section 2 is the modeling, including case analysis of farmers' land increment income payment modes and model construction. Section 3 includes the results and discussion. Section 4 offers the conclusions.

\section{Theoretical Framework}

\subsection{Definition}

China's rural land is collectively owned by farmers with a few exceptions, and it is divided into three categories according to land use purposes, namely rural collectively owned non-operating construction land, agricultural land, and RCOCL (Figure 1).

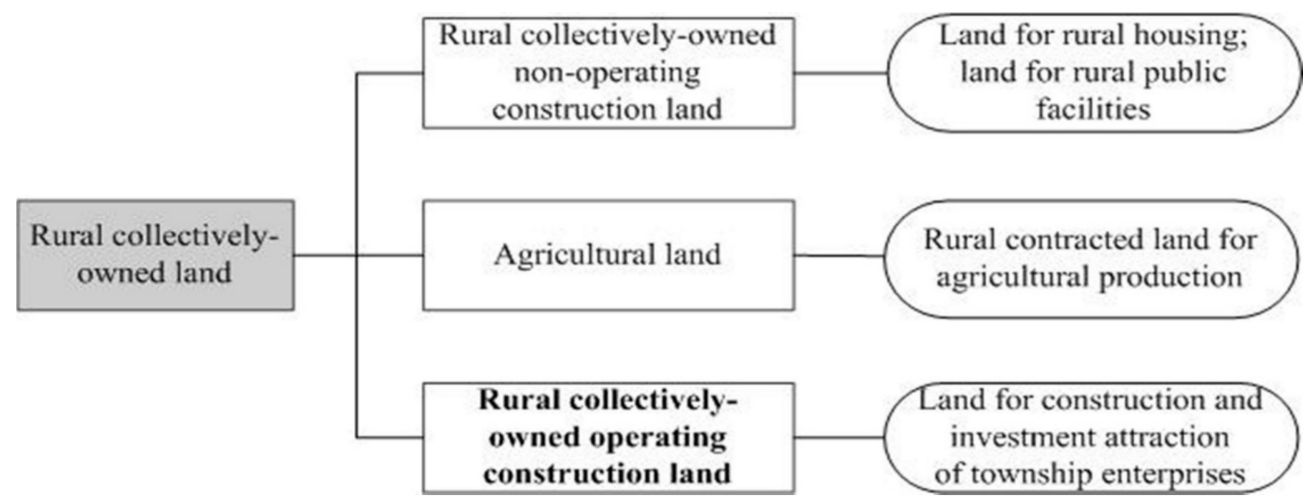

Figure 1. China's rural land reclassification. Source: According to Zhou, Li, and Liu [26].

RCOCL refers to rural construction land with the nature of production and operation, such as rural collectively owned land used to establish rural (town) enterprises. RCOCL entering the market refers to the process by which the rural land owner transfers the RCOCL use right for a certain period to the right holder in the form of sales, leases, and shares. Land increment income refers to the remaining part of the land transfer fee less the land development cost.

\subsection{History of Changes in Rural China's Land Rights}

Before 1949, rural land was privately owned by farmers, and it could be freely operated, bought, sold, and leased under certain conditions. The distribution of land ownership was uneven. A few landlords occupied more of the land, whereas most farmers had little. To reduce social inequality and develop the social economy, China initiated comprehensive land reform between 1949 and 1952 [26]. The land reform changed the ownership system of landlords to a system of farmers and implemented a more even distribution based on the number of farmers [27].

To address the shortage of production materials and low productivity of households, the People's Commune was introduced into Chinese rural areas in 1958 to realize the cooperative production of farmers' families. The introduction of the People's Commune marked the establishment of collective land ownership in rural China.

This form of co-work and co-distribution led to a sharp decline in farmers' enthusiasm for production and low land-use efficiency. In 1978, the People's Commune disintegrated, and China explored the property rights system reform of the rural household contract responsibility system. Under this system, land ownership and land use rights were separated [27]. That is, the collective ownership of land in rural areas remained unchanged, land ownership remained within the collective, and the land use right belonged to the 
farmer household. This rural land ownership system made each farmer household a unit to produce independently and obtain benefits, which greatly stimulated farmers' enthusiasm for production and promoted economic development. At that stage, rural land was not allowed to be transferred.

With the development of urbanization and industrialization in China, a large number of farmers have flowed into cities to engage in non-agricultural production [28,29], and a large amount of farmland had been idle [30]. To improve the agricultural land use efficiency [31], China began a new round of land transfer reforms. It was not until 1984 that the No. 1 document of China's central government was proposed to encourage the gradual concentration of land for farming experts. In 2003, the Rural Land Contract Law stipulated that agricultural land contractual management rights could be transferred through subcontracting, leasing, interchange, or other methods.

However, the transfer of rural construction land use rights was still prohibited. Due to the policy restrictions, rural construction lands were left idle and inefficiently utilized [1]. According to data from the Ministry of Land and Resources in 2018, China's urban construction land area is 91,612 square kilometers, while the rural construction land area is 191,158 square kilometers, which is more than twice that of urban construction land [32]. To activate the rural land, increase the income of farmers' land property rights, establish a unified urban and rural land market, and promote rural revitalization, China has further deepened rural land system reform, including the three rights separation of agricultural land, the land expropriation system reform, the three rights separation of homesteads, and RCOCL entering the market.

From 2015 to August 2018, more than 10,000 RCOCL in 33 pilot counties (cities, districts) entered the market, covering an area of more than $90,000 \mathrm{mu}$, with a total price of about 25.7 billion. Putting RCOCL on the market demonstrated the value of collectively owned land, and the pilot areas received 2.86 billion from it. Among them, in Deqing County, Zhejiang Province, there have been 183 cases with 1347 acres of RCOCL successfully entering the market, and rural collective economic organizations and farmers have obtained a net income of 270 million yuan, benefiting more than 180,000 farmers, which accounted for $65 \%$ of the local farmers [33]. Putting RCOCL on the market has promoted a unified urban and rural construction land market, strengthened the ability to secure land for rural industrial development, and increased farmers' property income.

\subsection{Payment Modes and Farmers' Utility}

To judge whether the RCOCL can legally enter the market and detect the disputes and problems in advance, the central government selected 33 counties (or cities) to carry out the pilot reform in 2015. In 2020, the implementation of the new land management law marked the liberalization of RCOCL entering the market in China. These areas have developed different experiences for the management of RCOCL entering the market, for example, the means of the right-of-use transfer and the payment modes of the land increment income.

The payment modes of the land increment income for RCOCL entering the market are classified into three categories: namely, lump-sum currency payment, a mixed payment of pension and lump-sum currency, and a mixed payment of dividend and lump-sum currency. Lump-sum currency payment refers to a one-off payment to farmers in a single form of the land increment income for RCOCL entering the market, which can increase farmers' income in the short term; a mixed payment of pension and lump-sum currency means that the land increment income is paid to farmers in the form of lump-sum income and pension. Among them, lump-sum income is paid immediately and used for farmers' consumption and investment, while pension is deferred and used for farmers' social security; dividend payment is a mode in which the land increment income is paid to farmers in the form of a dividend. Unlike a mixed payment of pension and lump-sum currency, the deferred payment is a dividend. The dividend guarantees a continuous income for farmers. 
In the case of the same amount of current distribution, different payment modes will affect the utility and welfare of farmers [34]. First, different payment modes bring different psychological perceptions to farmers. Monetized lump-sum compensation can allow farmers to obtain all their income immediately, enhancing their psychological utility [35]. As a core component of social security resettlement, endowment insurance prevents endowment risks, which can reduce people's uncertainty about the future and further improve their subjective well-being and sense of gain in enhancing their psychological utility [36]. Second, the long-term benefits that different payment models bring to farmers are different. Land conversion into shares can enable farmers to participate in the distribution of enterprise profits. If the profit margin of the enterprise is high, it can effectively increase farmers' longterm income. Under different conditions, the payment mode of land increment income affects farmers' utility and welfare. For example, when there are differences in the regional economic development level, the increment income obtained by farmers, and farmers' heterogeneity, the same land increment income payment mode will affect farmers' marginal utility [37]. This makes farmers with different economic development levels, increment income, and characteristics have different preferences for income payment modes [34].

When farmers participate in land rights transfer, they will not only consider the current benefits, but also long-term benefits and utility. Therefore, the different long-term psychological effects of farmers caused by different payment models of compensation affect farmers' enthusiasm to participate in the transfer of land rights. Existing studies on land acquisition, land use rights transfer, and ecological services programs have shown that the increase in economic compensation increase does not necessarily increase the enthusiasm of farmers to participate in [38-40]. By including diversified payment methods that take into account the long-term benefits of farmers, such as providing pension, share dividends, employment training, etc., can further enhance farmers' willingness to participate in related programs [41,42]. Therefore, designing and then selecting the increment income payment mode in different situations is important for RCOCL to enter the market.

\section{Modeling}

\subsection{Payment Modes of Land Increment Income Obtained by Farmers}

We comprehensively considered regional economic differences, the typicality of payment modes, and the details of the cases, and selected Xinghua City in Jiangsu Province, Meitan County in Guizhou Province, and Pidu District in Sichuan Province as the case study objects. In order to compare regional economic differences, we ranked the per capita GDP in 2019 of China's provinces and then did the same for counties (cities, districts). The results showed that Jiangsu Province, Sichuan Province, and Guizhou Province are respectively developed provinces, moderately developed provinces, and underdeveloped provinces; Xinghua City, Pidu District, and Meitan County are divided into developed regions, medium developed regions, and underdeveloped regions. Based on this, we choose these three regions as the case study areas (Figure 2).

\subsubsection{Tucao Village: Lump-Sum Currency Payment}

Tucao Village is in Meitan County, Zunyi City, Guizhou Province, an underdeveloped area of southwest China. GDP per capita of Guizhou Province in 2019 was 29,939 yuan, which is $57.77 \%$ lower than the national average. Tucao Village is a Class 1 poor village in Guizhou Province. Farmers' disposable income per capita is 14,726 yuan, and the main source of income was farming.

In August 2015, $3332 \mathrm{~m}^{2}$ of RCOCL in Tucao Village successfully entered the market by auction, which was the first case of RCOCL in China being legally traded on the market. The RCOCL was an abandoned brick factory and was used to build a one-stop area integrating catering, accommodation and refueling. The land-use right of the RCOCL was acquired by an individual for 800 thousand yuan [43]. Farmers got all the land increment income at one time (Table 1). 


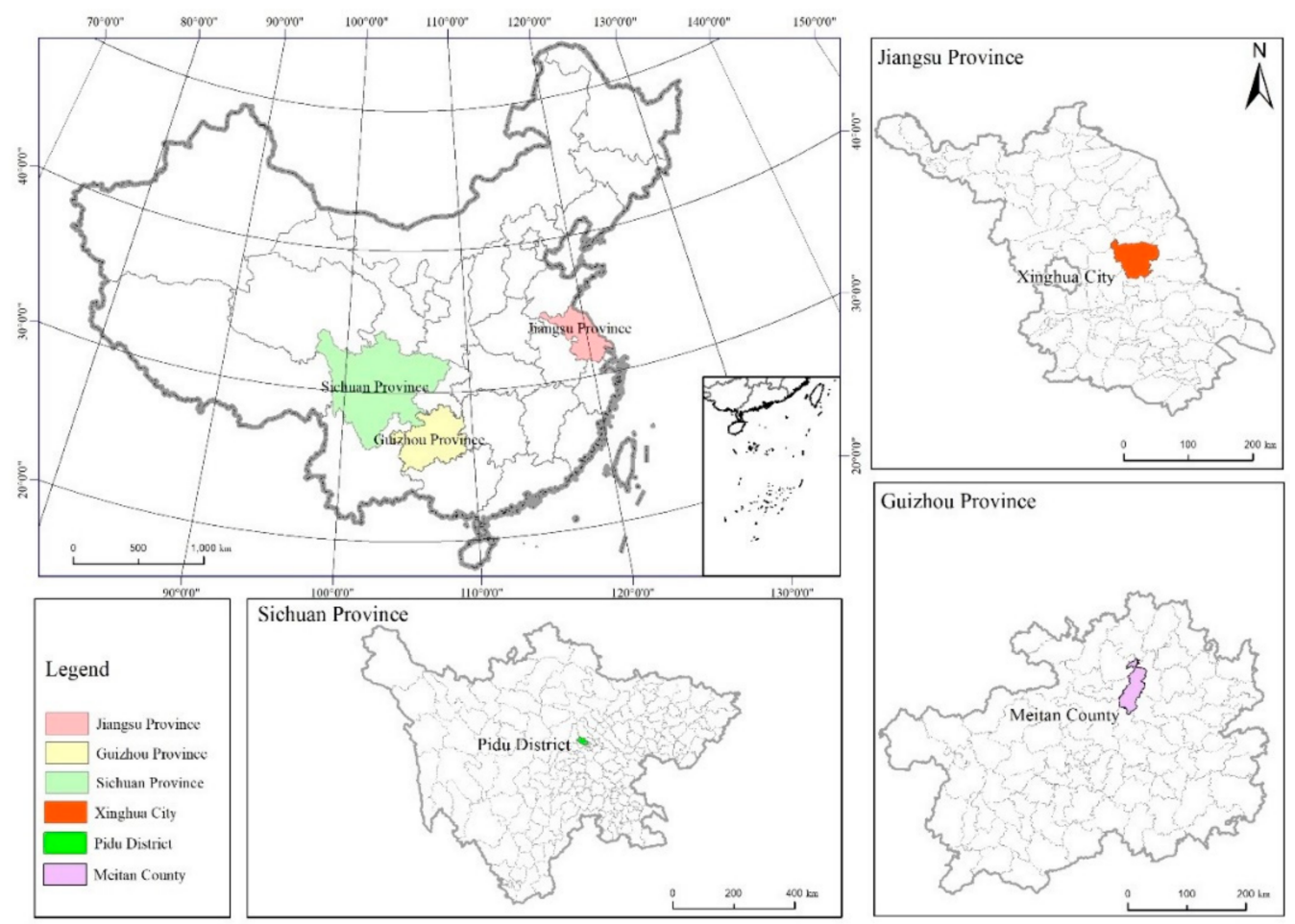

Figure 2. Locations of Meitan County, Pidu District, and Xinghua City.

Table 1. Comparison of three payment modes.

\begin{tabular}{|c|c|c|c|}
\hline Payment Mode & Form & Area & Economic Development \\
\hline Lump-sum payment & Cash & Meitan County & $\begin{array}{l}\text { Historically low economic } \\
\text { level with a stable economic } \\
\text { growth driven by the land } \\
\text { reform; emerged from a } \\
\text { poverty level in } 2018\end{array}$ \\
\hline $\begin{array}{l}\text { A mix of pension and } \\
\text { partial lump-sum } \\
\text { payment }\end{array}$ & Pension and cash & Pidu District & $\begin{array}{c}\text { At a medium economic } \\
\text { development level; electronic } \\
\text { information, bioengineering, } \\
\text { and new medical technology } \\
\text { are the main industries; rated } \\
\text { as one of the top } 100 \text { Science } \\
\text { and Technology Innovation } \\
\text { districts in } 2018\end{array}$ \\
\hline Dividend payment & Dividend & Xinghua City & $\begin{array}{c}\text { At a high economic } \\
\text { development level; } \\
\text { diversified natural resources; } \\
\text { historically known as the } \\
\text { "land of fish and rice" and is } \\
\text { a National Regional Tourism } \\
\text { Demonstration area }\end{array}$ \\
\hline
\end{tabular}

\subsubsection{Zhanqi Village: A Mixed Payment of Pension and Lump-Sum Currency}

Zhanqi Village is in Pidu District, Chengdu City, Sichuan Province, which is a developing region of southwest China. In 2019, the GDP per capita of Sichuan Province was 55,774 yuan, which is $21.33 \%$ lower than the national average. Farmers' disposable income per capita was 28,559 yuan, and the main sources of income were farming and work.

In September 2015, $13.447 \mathrm{mu}$ of RCOCL in Zhanqi Village successfully entered the market by listing. The Wallace Company bid for the right-of-use for 40 years with a unit price of 525,000 yuan per mu and a total price of 7.06 million yuan. The RCOCL was 
originally used for a compound fertilizer factory, prefabricated factory, and an old office building of the village committee run by the village collective. After entering the market, a rural tourism complex project integrating a gourmet experience, agricultural sightseeing, and leisure was built. The land increment income was divided into two parts, $20 \%$ of it was distributed to members of the village collective economic organization in cash, and the other part used as social security (Table 1) [44].

\subsubsection{Dongluo Village: Dividend Payment}

Dongluo Village is located in Xinghua City, Taizhou City, Jiangsu Province, which is a developed region of east China. In 2019, the GDP per capita of Jiangsu Province was 123,607 yuan, which is $74.36 \%$ higher than the national average. Xinghua City is a countylevel city under the authority of Jiangsu Province, and it was one of the top 100 industrial counties in China in 2020. Farmers' disposable income per capita is 23,116 yuan per year in 2019 , and the main sources of income were farming, work, and dividends.

In December 2020, $18.49 \mathrm{mu}$ of RCOCL in Dongluo Village successfully traded in the market. In September 2020, This RCOCL was delisted by Wanxing Commercial Management Co., Ltd. Farmers used the land increment income of 5.4 million as the capital of the enterprise to hold the shares of the enterprise and to get dividends. It is guaranteed that the annual dividend would be at least 80,000 yuan (Table 1) [45].

\subsection{Model Construction}

\subsubsection{Lump-Sum Currency Payment}

We assume that farmers who participate in the marketization of RCOCL live for two periods, young and old age. For a farmer who is young in the period $t$, the utility function to be maximized is written as:

$$
U\left(C_{t}^{Y}, A_{t}^{Y}\right)+U\left(C_{t+1}^{o}\right)
$$

where $U($.$) is the utility function, C_{t}^{Y}$ is the consumption of the young in period $t$ [46], $A_{t}^{Y}$ is the land increment income obtained by the young in period $t$, and $C_{t+1}^{O}$ is the consumption of the old in period $t+1$ [47]. We assume that farmers are risk-neutral. The utility function is assumed to be $U(Y)=\ln Y$. Then, the farmers' utility function can be represented as:

$$
U=a \ln C_{t}^{Y}+b \ln A_{t}^{Y}+c \ln C_{t+1}^{O}
$$

where $a, b$, and $c$ represent the elasticity of utility from consumption in their youth, the land increment income that farmers obtained in the young, and consumption in their old age respectively; $c=\frac{a}{1+\rho}$, where $\rho$ is the time preference rate.

At a young age, there are two sources of income. First, farmers supply a unit of inelastic labor and receive wages $W_{t}$. Second, they can get the land increment income $A_{t}^{Y}$ if they agree to transfer their land. In a lump-sum payment, farmers get all the land increment income at one time, which is equal to the proportion of land increment income in land transfer fee $\omega$ times the land transfer fee. The land transfer fee is equal to the land transfer price $P_{t}^{L}$ times land transfer area $L$. We assume all the land increment income farmers obtained is $I$; that is, $A_{t}^{Y}=I=\omega P_{t}^{L} L$. All of that is spent on consumption $C_{t}^{Y}$ and savings $S_{t}$. Farmers will face the budget constraint

$$
C_{t}^{Y}+S_{t}=W_{t}+I
$$

At an old age, farmers do not work, and they can get interest on their savings $r_{t+1} S_{t}$, where $r_{t+1}$ is equal to $1+e_{t+1} ; e_{t+1}$ is the deposit interest rate in period $t+1$, and all of that is spent on consumption $C_{t+1}^{O}$. Then, we can get the budget constraint of the elderly consumption of farmers.

$$
C_{t+1}^{o}=\left(1+e_{t+1}\right) S_{t}
$$


Equations (3) and (4) can be combined to get the lifetime budget constraint represented in Equation (5). With this constraint, farmers choose $C_{t}^{Y}$ and $C_{t+1}^{O}$ to maximize (2):

$$
C_{t}^{Y}+\frac{C_{t+1}^{0}}{1+e_{t+1}}=W_{t}+I
$$

In addition to capital $K$ and labor $N$, the production factors of an enterprise also include land $L$ [48]. The production technology is the production function with a constant returns to scale:

$$
Y_{t}=F\left(K_{t}, N_{t}, L_{t}\right)
$$

where $Y_{t}$ is the total output of an enterprise. In China, the capital of an enterprise is not completely determined by itself but also influenced by other factors such as the bank loan [49]. However, to make a profit, for the enterprise that participated in the marketization of RCOCL, the marginal return on capital must be greater than or equal to the market rate of interest; that is, $F_{K}\left(K_{t}, N_{t}, L_{t}\right) \geq r_{t}$; similarly, the labor of an enterprise is not completely determined in isolation but also influenced by the supply of labor [50]. However, for an enterprise, the marginal return on labor must be greater than or equal to wages; that is, $F_{N}\left(K_{t}, N_{t}, L_{t}\right) \geq W_{t}$. Therefore, we regard capital and labor as exogenous variables. Land-use rights are publicly traded on the land trading platform through bidding, auction, and listing, and the market price of land is determined by several enterprises competing. Therefore, the land market can be regarded as a perfectly competitive market. Under certain capital and labor constraints, to obtain the maximum profit, the transaction price of land given by the winning enterprise should be equal to the marginal return of land, that is $F_{L}\left(K_{t}, N_{t}, L_{t}\right)=P_{t}^{L}$.

\subsubsection{A Mixed Payment of Pension and Lump-Sum Currency}

In a mixed payment of pension and partial lump sum, the land increment income obtained by farmers includes two forms. One is the lump-sum payment obtained in period $t$, and the other is the pension obtained in period $t+1$. We assume that the proportion of pension in land increment income is $\theta(0<\theta<1)$ and the proportion of lump-sum payment in land increment income is $1-\theta$. We can determine that the land increment income obtained by farmers in their youth is written as $A_{t}^{Y}=(1-\theta) I$.

At a young age, the source of income has two parts, wages $W_{t}$ and the lump-sum payment $(1-\theta) I$. All of that is spent on consumption $C_{t}^{Y}$ and saving $S_{t}$. Farmers will face the new budget constraint in period $t$ :

$$
C_{t}^{Y}+S_{t}=W_{t}+(1-\theta) I .
$$

At an old age, there are also two sources of income: (1) saving in the young and interest on their saving of $\left(1+r_{t+1}\right) S_{t}$ and (2) the pension of $(1+\varphi) \theta I$, where $\varphi$ is the pension rate of return, and all of that is spent on consumption $C_{t+1}^{O}$. Then, we can get the budget constraint of the consumption of farmers in the period $t+1$.

$$
C_{t+1}^{o}=(1+\varphi) \theta I+\left(1+e_{t+1}\right) S_{t}
$$

Equations (6) and (7) can be combined to get the lifetime budget constraint. With the constraint of (8), farmers choose $C_{t}^{Y}, C_{t+1}^{O}$, and $\theta$ to maximize (2).

$$
C_{t}^{Y}+\frac{C_{t+1}^{0}}{1+e_{t+1}}=W_{t}+(1-\theta) I+\frac{(1+\varphi) \theta I}{1+e_{t+1}}
$$

\subsubsection{A Mixed Payment of Dividend and Lump-Sum Currency}

When farmers choose to become a shareholder to participate in income distribution, the income they get from the enterprise will be divided into three parts: lump-sum payment, dividends, and the discounted present value of the stock rights. We assume the proportion 
of the income used to take stakes in the enterprise in land increment income is $\lambda(0<\lambda<1)$, and $1-\lambda$ is the proportion of lump-sum payment in land increment income.

Similarly, the income of the young includes wages $W_{t}$ and the lump-sum payment $A_{t}^{Y}=(1-\lambda) I$. Therefore, the budget constraint of the young in period $t$ is written as

$$
C_{t}^{Y}+S_{t}=W_{t}+(1-\lambda) I
$$

At an old age, the farmers' dividends are $v \pi_{t+1}$, where $v$ is the proportion of the farmer's shares in the enterprise and $\pi_{t+1}$ is the profit of the enterprise in the period $t+1$. The discounted present value of farmers' stock rights is $\mu \lambda I$, where $\mu$ is the discount rate of the stock rights. We can take dividends and the discounted present value of the stock rights as the return obtained by investing $\lambda I$ into the enterprise, and the return on investment is $\sigma=\frac{v \pi_{t+1}+\mu \lambda I}{\lambda I}$. The profit of the enterprise $\pi_{t+1}$ fluctuates over a certain period, and it is affected by enterprise-scale, industrial concentration, factor productivity, human capital, etc. [51,52]. We can take $\pi_{t+1}$ as a random variable, and accordingly, $\sigma$ can be treated as a random variable whose probability density function is $f(\sigma)$. Then, the expected rate of return on investment is $E(\sigma)=\int_{\sigma}^{\bar{\sigma}} \sigma f(\sigma) d \sigma$, where $\bar{\sigma}$ is the maximum of $\sigma$ and $\sigma$ is the minimum of $\sigma[53,54]$. Therefore, the budget constraint of the old in period $t+1$ is written as

$$
C_{t+1}^{o}=[1+E(\sigma)] \lambda I+\left(1+e_{t+1}\right) S_{t} .
$$

Equations (9) and (10) can be combined to get the lifetime budget constraint. With the constraint of (11), farmers choose $C_{t}^{\gamma}, C_{t+1}^{O}$, and $\lambda$ to maximize (2).

$$
C_{t}^{Y}+\frac{C_{t+1}^{0}}{1+e_{t+1}}=W_{t}+(1-\lambda) I+\frac{[1+E(\sigma)] \lambda I}{1+e_{t+1}}
$$

\section{Results}

\subsection{Select the Optimal Payment Mode}

Comparing the payment modes (lump-sum currency payment, a mix of pensions and partial lump-sum payment, and dividends payment), we can write the model in the following generalized form.

$$
\begin{gathered}
U=a \ln C_{t}^{Y}+b \ln A_{t}^{Y}+c \ln C_{t+1}^{O} \\
C_{t}^{Y}+S_{t}=W_{t}+A_{t}^{Y} \\
C_{t}^{Y}+\frac{C_{t+1}^{0}}{1+e_{t+1}}=W_{t}+A_{t}^{Y}+\frac{(1+\gamma)\left(1-A_{t}^{Y}\right)}{1+e_{t+1}}
\end{gathered}
$$

where $A_{t}^{Y}=(1-\beta) I, I=\omega P_{t}^{L} L, \beta$ is OPPSC, $\gamma$ is the pension rate of return or the expected return rate of the stock capital. When $\gamma$ is equal to 0 , a lump-sum payment is adopted; when $0<\beta \leq 1$, the mixed payment of pension and partial lump sum or a mixed payment of dividend and partial lump sum is adopted.

The optimal solution to $\beta$ for maximizing farmers' utility, based on the assumption that $0 \leq \beta \leq 1, \gamma>e_{t+1}$, is given as follows:

$$
\beta=\left\{\begin{array}{cl}
0 & \text { if } P_{t}^{L} \leq \frac{b\left(1+e_{t+1}\right) W_{t}}{(a+c)\left(\gamma-e_{t+1}\right) \omega L-b \omega L\left(1+e_{t+1}\right)} \\
\frac{(a+c)\left(\gamma-e_{t+1}\right)-b\left(1+e_{t+1}\right)\left(\frac{W_{t}}{\omega P_{t}^{L} L}+1\right)}{(a+b+c)\left(\gamma-e_{t+1}\right)} & \text { if } P_{t}^{L}>\frac{b\left(1+e_{t+1}\right) W_{t}}{(a+c)\left(\gamma-e_{t+1}\right) \omega L-b \omega L\left(1+e_{t+1}\right)}
\end{array}\right.
$$

According to the analysis described above, we conclude that the optimal payment mode is as follows:

When the transfer price of RCOCL is below a specific value, which is $\left[b\left(1+e_{t+1}\right) W\right] /$ $\left[(a+c)\left(\gamma-e_{t+1}\right) \omega L-b \omega L\left(1+e_{t+1}\right)\right]$, a lump-sum payment can bring maximum utility 
to farmers. Thus, it is more appropriate to adopt the lump-sum payment. If the transfer price of RCOCL is higher than the specific value, the mixed payment of lump-sum currency and pension or the mixed payment of lump-sum currency and dividend is the optimal payment mode.

When the transfer price of RCOCL is higher than the specific value, it is necessary to compare the maximum utility of the mixed payment of lump sum and pension with the mixed payment of lump sum and dividend to determine which payment mode to adopt.

Under the optimal $\beta$, the farmers' maximum utility is written as:

$$
U_{M A X}=a \ln \frac{a\left[I(1+\gamma)+W_{t}\left(1+e_{t+1}\right)\right]}{\left(1+e_{t+1}\right)(a+b+c)}+b \ln \frac{b\left[I(1+\gamma)+W_{t}\left(1+e_{t+1}\right)\right]}{(a+b+c)\left(\gamma-e_{t+1}\right)}+c \ln \frac{c\left[I(1+\gamma)+W_{t}\left(1+e_{t+1}\right)\right]}{a+b+c} .
$$

Equation (17) shows that the farmers' maximum utility is affected by $\gamma$. That means the farmers' maximum utility varies with the pension rate of return or the expected return rate of the stock capital. Therefore, we take the derivative of $U_{M A X}$ for $\gamma$ and get the effect of $\alpha$ on $U_{M A X}$, to determine which mode of the mixed payment of pension and partial lump sum or the mixed payment of dividend and partial lump sum can bring more utility to farmers. The derivative of $U_{M A X}$ for $\gamma$ gives:

$$
U_{\gamma}=\frac{(a+c)\left(\gamma-e_{t+1}\right) I-b\left(1+e_{t+1}\right)\left(I+W_{t}\right)}{\left[I(1+\gamma)+W_{t}\left(1+e_{t+1}\right)\right]\left(\gamma-e_{t+1}\right)}
$$

which is higher than 0 as $P_{t}^{L}>\left[b\left(1+e_{t+1}\right) W\right] /\left[(a+c)\left(\gamma-e_{t+1}\right) \omega L-b \omega L\left(1+e_{t+1}\right)\right]$, so $U$ and $\gamma$ are positively correlated. It means the higher the $\gamma$ is, the higher the farmers' maximum utility $U_{M A X}$. That is, when the land transfer price of RCOCL is higher than a specific value, the mode that should be taken depends on the pension rate of return and expected return rate of stock capital, which of the two will bring greater utility to farmers, and which corresponding payment mode is more appropriate. Therefore, it can be concluded that if the pension rate of return is greater than the expected return rate of stock capital, the mixed payment of pension and lump sum is more appropriate; otherwise, the mixed payment of dividend and lump sum is more appropriate.

Thus, we can conclude the process of selecting the optimal payment mode (Figure 3) and the optimal payment mode of RCOCL entering the market (Table 2) (1) if the transfer price of RCOCL is below $\left[b\left(1+e_{t+1}\right) W\right] /\left[(a+c)\left(\gamma-e_{t+1}\right) \omega L-b \omega L\left(1+e_{t+1}\right)\right]$, the lumpsum payment is the optimal payment mode; (2) if the transfer price of RCOCL is higher than $\left[b\left(1+e_{t+1}\right) W\right] /\left[(a+c)\left(\gamma-e_{t+1}\right) \omega L-b \omega L\left(1+e_{t+1}\right)\right]$, and the pension rate of return is higher than the expected return rate of stock capital, the mixed payment of pension and lump sum is the optimal payment mode; if the transfer price of RCOCL is higher than $\left[b\left(1+e_{t+1}\right) W\right] /\left[(a+c)\left(\gamma-e_{t+1}\right) \omega L-b \omega L\left(1+e_{t+1}\right)\right]$, and the pension rate of return is smaller than the expected return rate of stock capital, the mixed payment of dividend and lump sum is optimal.

\subsection{Determining OPPSC}

\subsubsection{Calibration of Parameters}

From Equation (15), OPPSC is influenced by these factors: $\left\{a, b, c, e_{t+1}, \gamma, \omega, L, W_{t}, P_{t}^{L}\right\}$. We analyzed the impact of key indicators among these factors on OPPSC. Based on reality, we select the following indicators: the marginal utility elasticity of the lump-sum payment $b$, which reflects farmers' heterogeneity; the expected return rate of the stock capital $\gamma$, which reflects the enterprise profit margin; the proportion of land increment income in land transfer fee $\omega$, which reflects the land development cost; the wages $W_{t}$, which reflects local economic development level; the land transfer price $P_{t}^{L}$, which reflects the industry to which RCOCL enters the market. 


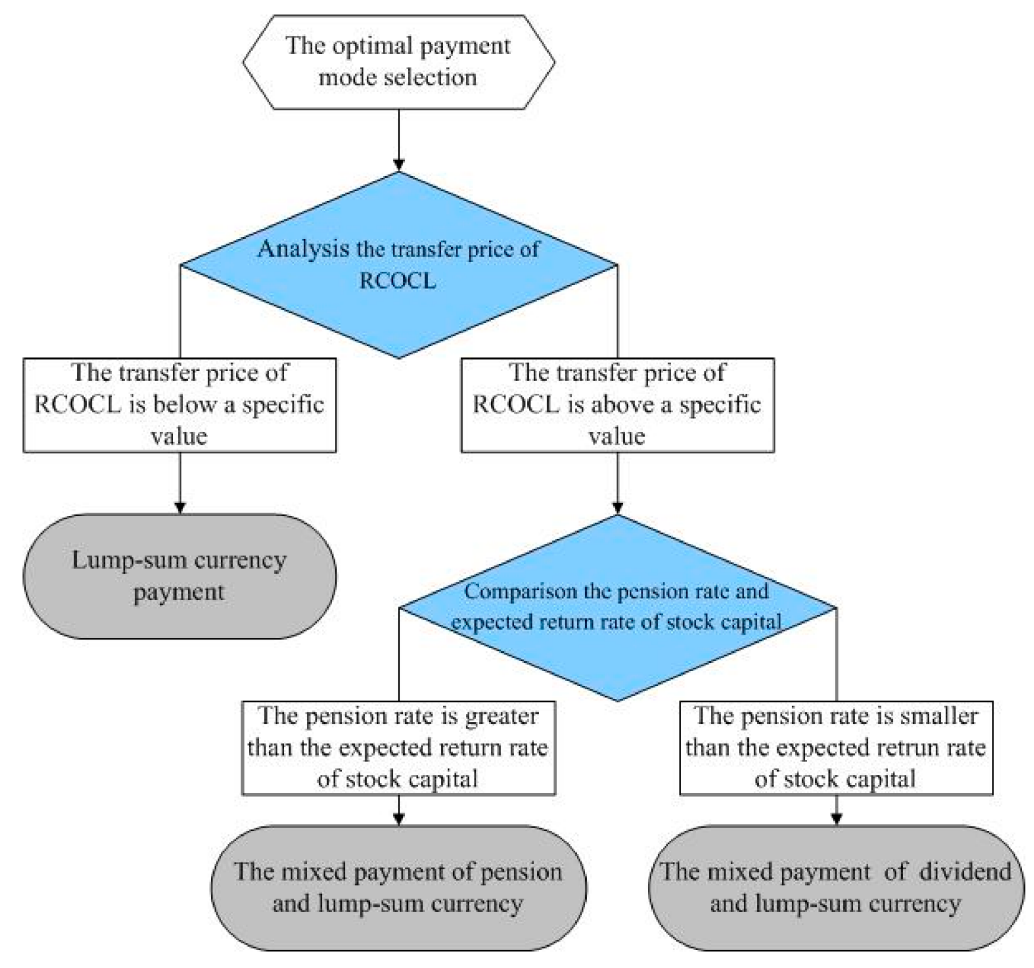

Figure 3. The process of selecting the optimal payment mode.

Table 2. The preference of optimal payment mode.

\begin{tabular}{ccc}
\hline $\begin{array}{c}\text { The Optimal Payment } \\
\text { Mode }\end{array}$ & The Transferring Fee of RCOCL & $\begin{array}{c}\text { Comparison of the Pension Rate of } \\
\text { Return and the Expected Return Rate of } \\
\text { Stock Capital }\end{array}$ \\
\hline $\begin{array}{c}\text { Lump-sum currency } \\
\text { payment }\end{array}$ & {$\left[b\left(1+e_{t+1}\right) W\right] /\left[(a+c)\left(\gamma-e_{t+1}\right) \omega L-b \omega L\left(1+e_{t+1}\right)\right]$} & $/$ \\
\hline $\begin{array}{c}\text { A mixed payment of } \\
\text { pension and } \\
\text { lump-sum currency }\end{array}$ & {$\left[b\left(1+e_{t+1}\right) W\right] /\left[(a+c)\left(\gamma-e_{t+1}\right) \omega L-b \omega L\left(1+e_{t+1}\right)\right]$} & $\begin{array}{c}\text { The pension rate of return is greater than } \\
\text { the expected return rate of stock capital }\end{array}$ \\
\hline $\begin{array}{c}\text { A mixed payment of } \\
\text { dividend and } \\
\text { lump-sum currency }\end{array}$ & {$\left[b\left(1+e_{t+1}\right) W\right] /\left[(a+c)\left(\gamma-e_{t+1}\right) \omega L-b \omega L\left(1+e_{t+1}\right)\right]$} & $\begin{array}{c}\text { The pension rate of return is smaller than } \\
\text { the expected return rate of stock capital }\end{array}$ \\
\hline
\end{tabular}
Table 3.

Before analysis, we calibrated common parameters, and the results are shown in

The elasticity of marginal utility of consumption in farmers' youth $a$ is set to 1.4 [46]. The time preference rate $\rho$ is set to 0.4 , which is more aligned with the actual Chinese situation [55]. Thus, we set the marginal utility elasticity of consumption in farmers' old $c$ to 1 [46]. We assume 40 years from youth to old age. Therefore, we set the deposit interest rate $e_{t+1}$ to 0.79 with the annual deposit interest rate equal to $1.5 \%$, which is from General Office of the People's Bank of China (http:/ / www.pbc.gov.cn/, accessed on 23 October 2015). According to the China Social Security Fund Council Social Security Fund Report in 2019 (http:/ / www.ssf.gov.cn/, accessed on 24 November 2020), the annual pension rate of return is $8.14 \%$. Following $e_{t+1}$, we can determine that the pension rate of return $\gamma$ is 20.16. According to the data from The State Council Information Office, which held a press conference on the adjustment and improvement of the relevant documents concerning the use of land transfer income (http:/ / www.gov.cn/xinwen/2020-09/24/content_5546664. $\mathrm{htm}$, accessed on 24 September 2020), $\omega$ is set to $19.2 \%$. The marginal utility elasticity of the lump-sum payment $b$ is set to 1.26 [47]. 
Table 3. Calibration of parameters.

\begin{tabular}{|c|c|c|c|}
\hline Parameters & Value & Description & Data Source \\
\hline$a$ & 1.4 & $\begin{array}{l}\text { The marginal utility elasticity of } \\
\text { consumption in the youth }\end{array}$ & EVANS [46] \\
\hline$b$ & 1.26 & $\begin{array}{l}\text { The marginal utility elasticity of the } \\
\text { lump-sum currency payment }\end{array}$ & Lans Bovenberg and Smulders [55] \\
\hline$c$ & 1 & $\begin{array}{l}\text { The marginal utility elasticity of } \\
\text { consumption in the old }\end{array}$ & EVANS [46] \\
\hline$e_{t+1}$ & 0.79 & The deposit interest rate & $\begin{array}{c}\text { General Office of the People's Bank of China } \\
\text { http:/ / www.pbc.gov.cn/, (accessed on } \\
23 \text { October 2015) }\end{array}$ \\
\hline$\gamma$ & 20.16 & The pension rate of return & $\begin{array}{l}\text { China Social Security Fund Council Social } \\
\text { Security Fund Report http:/ / www.ssf.gov.cn/, } \\
\text { (accessed on } 24 \text { November 2020) }\end{array}$ \\
\hline$\omega$ & $19.2 \%$ & $\begin{array}{l}\text { The proportion of land increment } \\
\text { income in land transfer fee }\end{array}$ & $\begin{array}{l}\text { The State Council Information Office } \\
\text { http://www.gov.cn/xinwen/2020-09/24 } \\
\text { / content_5546664.htm, (accessed on } \\
\text { 24 September 2020) }\end{array}$ \\
\hline$L$ & 0.5 & The land transfer area & / \\
\hline
\end{tabular}

In addition, the land transfer area $L$ requires calibration. Land transfer area is an exogenous variable, not a regular parameter. Thus, it needs to be standardized to a value between 0 and 1 to facilitate analysis. In this paper, we set it to 0.5 , regardless of its impact on OPPSC. We also standardize wages $W_{t}$ and the land transfer price $P_{t}^{L}$.

\subsubsection{The Land Marginal Return of Enterprises and OPPSC}

Figure 4 shows that the land transfer price and OPPSC are positively correlated. Since the land transfer price cannot equal 0 , we assume that the minimum value is 0.1 .

Figure $4 \mathrm{a}$ exhibits the relationship between the land transfer price and OPPSC when the wage changes. When other values are constant, regardless of $W_{t}$ and $P_{t}^{L}, \beta$ is between 0 and $62.39 \%$, and it is centered at $30 \%$. When $W_{t}$ is lower than $0.5, \beta$ is between 0 and $62.39 \%$ at any $P_{t}^{L}$, with a median of $31.2 \%$; when $W_{t}$ is higher than $0.5, \beta$ is between 0 and $45.82 \%$ at any $P_{t}^{L}$, with a median of $22.91 \%$. When the wage is higher, $\beta$ increases more with the increase of $P_{t}^{L}$; when the wage is lower, $\beta$ increases less with the increase of $P_{t}^{L}$. Thus, if the land marginal return of enterprises participating in the market increases by a certain percentage, the OPPSC increase in developed regions will be higher than that in underdeveloped regions.

Figure $4 \mathrm{~b}$ shows the relationship between the land transfer price and OPPSC when the proportion of land increment income in land transfer fee changes. In this case, since the land transfer price cannot be equal to 0 , we assume that the minimum $\omega$ is 0.1 . When other values are constant, regardless of $\omega$ and $P_{t}^{L}, \beta$ is between 0 and $62.77 \%$. When $\omega$ is lower than $0.5, \beta$ is between 0 and $61.36 \%$ at any $P_{t}^{L}$, with a median of $30.68 \%$; when $\omega$ is higher than 0.5 , then $\beta$ is between $36.09 \%$ and $62.77 \%$, with a median of $49.43 \%$. When the $\omega$ is lower, $\beta$ increases more with the increase of $P_{t}^{L}$; when the $\omega$ is higher, $\beta$ increases less with the increase of $P_{t}^{L}$. Thus, if the land marginal return of the enterprise is constant, when the development cost of RCOCL that entered the market is high, OPPSC will be lower than the situation in which the land development cost is low.

Figure $4 \mathrm{c}$ shows the relationship between the land transfer price and the optimal proportion of stock capital in land increment income when the expected return rate of the stock capital changes. As $\gamma$ and $P_{t}^{L}$ change, $\beta$ changes between 0 and $56.29 \%$. If $\gamma$ is higher than $20, \beta$ will vary from $0 \%$ to $56.29 \%$ as $P_{t}^{L}$ changes; if $\gamma$ is lower than 20 , will vary from $0 \%$ to $45.66 \%$ as $P_{t}^{L}$ changes. When $\gamma$ is at a higher level, $\beta$ increases at a higher rate with the increase of $P_{t}^{L}$; when $\gamma$ is at a lower level, $\beta$ increases at a lower rate with the increase 
of $P_{t}^{L}$. Therefore, if the land marginal return of enterprises participating in the market increases by a certain percentage, OPPSC increase for the enterprise with a higher profit margin will be higher than that for an enterprise with a lower profit margin.

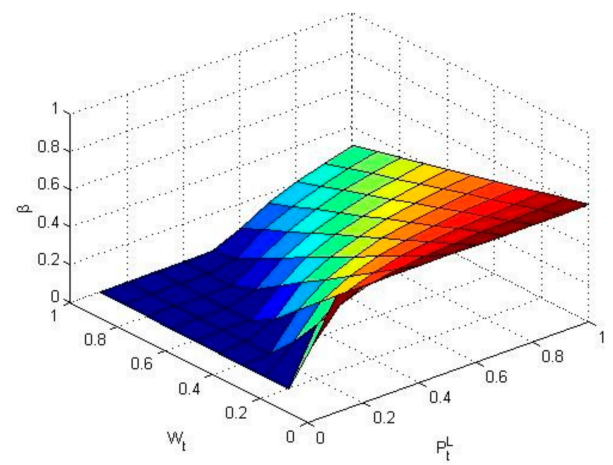

(a)

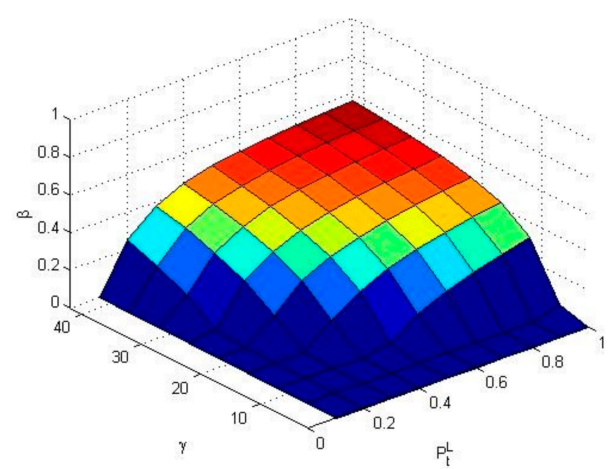

(c)

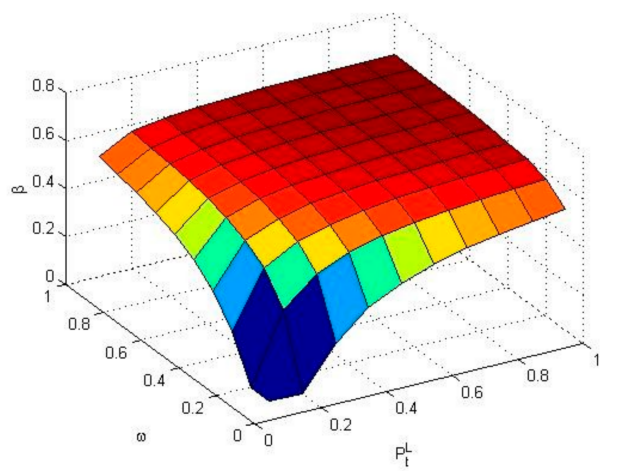

(b)

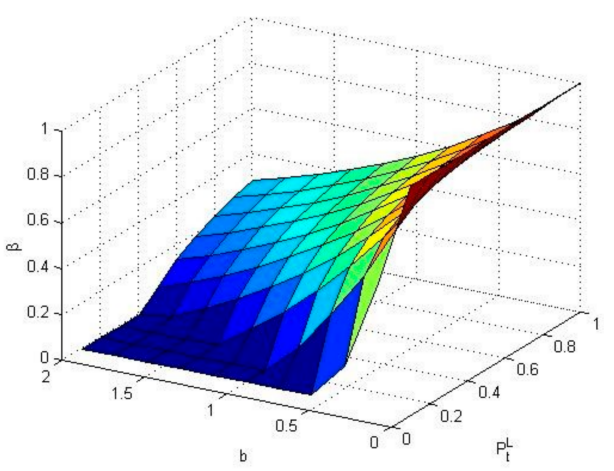

(d)

Figure 4. The land marginal return of enterprises and OPPSC under (a) different wages, (b) different proportions of land increment income in land transfer fee, (c) different expected return rates of the stock capital and (d) different marginal utility elasticities of the lump-sum currency payment.

Figure $4 \mathrm{~d}$ shows the relationship between the land transfer price and OPPSC when the marginal utility elasticity of the lump-sum currency payment changes. No matter how $b$ and $P_{t}^{L}$ change, $\beta$ is between 0 and $99.99 \%$. When both $b$ and $P_{t}^{L}$ are the largest, $\beta$ is $28.47 \%$. When $b$ is lower than $1, \beta$ is between 0 and $53.71 \%$ at any $P_{t}^{L}$, with a median of $26.86 \%$; when $b$ is higher than 1 , then $\beta$ is between $0 \%$ and $99.99 \%$, with a median of $50 \%$. When $b$ is less than 1 , as $P_{t}^{L}$ increases, $\beta$ increases faster than when $b$ is higher than 1 . So, when the land marginal return of enterprises participating in the market increases, OPPSC of farmers with less marginal utility elasticity of the lump-sum payment decreases faster.

\subsubsection{The Economic Development Level and OPPSC}

Figure 5 shows that the wage and OPPSC are negatively correlated.

Figure 4 a shows the relationship between the wage and OPPSC when the land transfer price changes. When $P_{t}^{L}$ is lower than $0.5, \beta$ is between 0 and $62.39 \%$ at any $W_{t}$; when $P_{t}^{L}$ is higher than $0.5, \beta$ is also between 0 and $62.39 \%$ at any $W_{t}$. When $P_{t}^{L}$ is lower, with the increase of $W_{t}, \beta$ decreases more; when $P_{t}^{L}$ is higher, with the increase of $W_{t}, \beta$ decreases less. Thus, for enterprises with higher land marginal returns, the worse the regional economic development level, the higher the OPPSC.

Figure 5a shows the relationship between the wage and OPPSC when the proportion of land increment income in land transfer fee changes. When other values are constant, regardless of $\omega$ and $W_{t}, \beta$ is between 0 and $62.39 \%$. Similarly, the minimum of $\omega$ is assumed to be 0.1 . If $\omega$ is lower than $0.5, \beta$ will be between 0 and $62.39 \%$ at any $W_{t}$, with a median of $31.20 \%$; if $\omega$ is higher than 0.5 , then $\beta$ is between $36.94 \%$ and $62.39 \%$, with a median 
of $49.67 \%$. Compared to when $\omega$ is higher, as $W_{t}$ increases, the rate at which $\beta$ decreases is higher than when $\omega$ is lower. So, if the development cost of RCOCL is higher, with an improvement of the regional economy, OPPSC will decrease over a large range; if the development cost of RCOCL is lower, with an improvement of the regional economy, OPPSC will decrease more slowly.

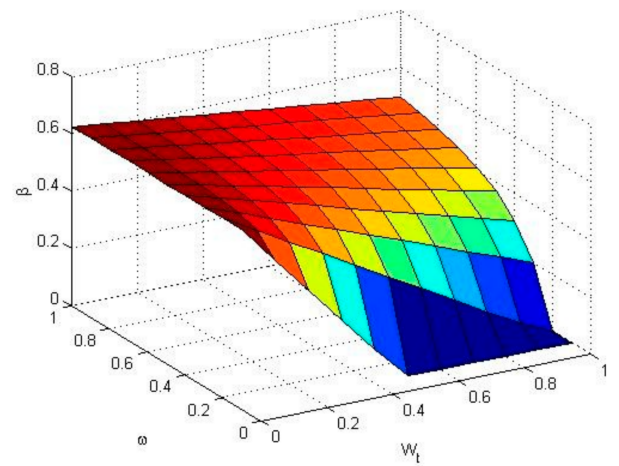

(a)

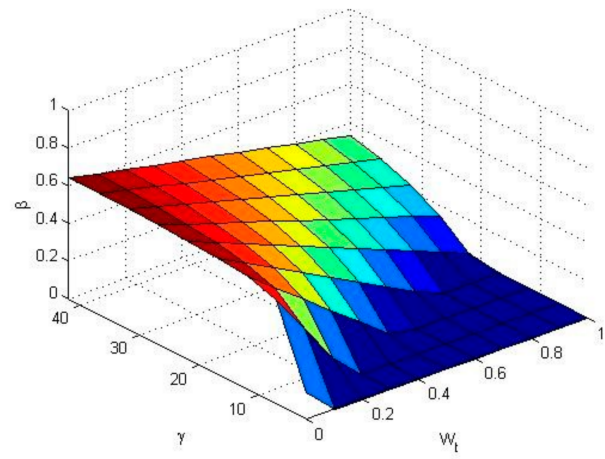

(b)

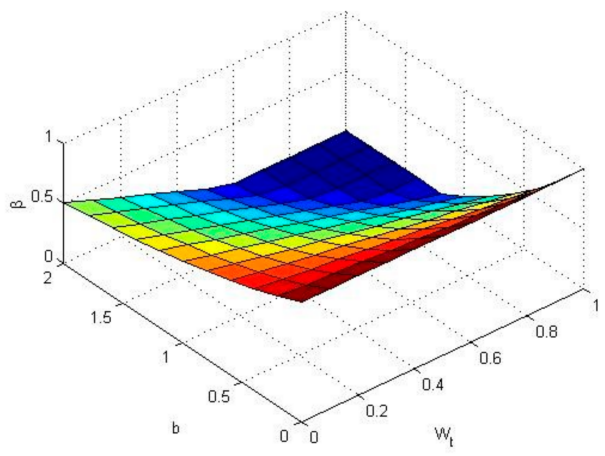

(c)

Figure 5. The economic development level and OPPSC under (a) different proportions of land increment income in land transfer fee, (b) different expected return rates of the stock capital and (c) different marginal utility elasticities of the lump-sum currency payment.

Figure 5 b shows the relationship between the wage and OPPSC when the expected return rate of the stock capital changes. As $\gamma$ and $W_{t}$ change, $\beta$ takes a value between 0 and $64.08 \%$. When $\gamma$ is higher than $20, \beta$ decreases from $64.08 \%$ to 0 as $W_{t}$ increases; when $\gamma$ is lower than 20, $\beta$ decreases from $62.37 \%$ to 0 as $W_{t}$ increases, and it decreases faster than when $\gamma$ is above 20. This indicates when the regional economy improves, OPPSC in the enterprise with a higher profit margin decreases faster than the enterprise with a lower one. The lower the economic level, the higher the profit margin of enterprises entering the market, and the higher the OPPSC.

Figure $5 c$ shows the relationship between the wage and OPPSC when the marginal utility elasticity of the lump-sum payment changes. When other values are constant, regardless of $b$ and $W_{t}, \beta$ varies between 0 and $99.99 \%$. When $b$ is higher than $1, \beta$ decreases from $67.87 \%$ to 0 with $W_{t}$ increases; when $b$ is lower than $1, \beta$ decreases from $99.99 \%$ to $11.25 \%$ with $W_{t}$ increases, and it decreases slower than when $b$ is above 1 . Thus, when the marginal utility elasticity of the lump-sum payment of farmers is high, OPPSC decreases faster as compared to the situation in which the marginal utility elasticity of the lump-sum payment is low as the regional economic development level improves.

\subsubsection{An Enterprise's Profit Margin and OPPSC}

Figure 6 shows that the expected return rate of the stock capital and OPPSC are positively correlated. 


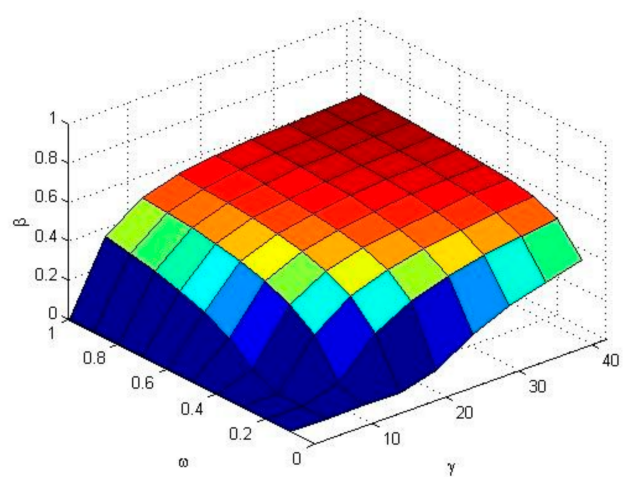

(a)

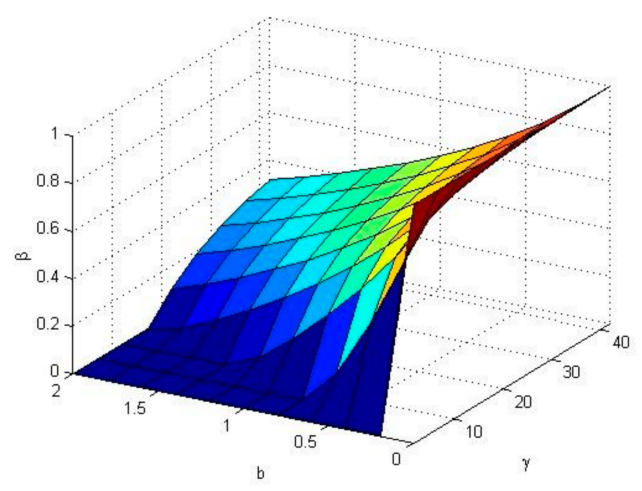

(b)

Figure 6. Enterprise's profit margin and OPPSC with (a) different proportions of land increment income in land transfer fee and (b) different marginal utility elasticities of the lump-sum currency payment.

Figure $4 \mathrm{c}$ shows the relationship between the expected return rate of the stock capital and the optimal proportion of stock capital in land increment income when the land transfer price changes. If $P_{t}^{L}$ is less than 0.5 , when $\gamma$ increases, $\beta$ will increase from 0 to $48.5 \%$; if $P_{t}^{L}$ is higher than 0.5 , when $\gamma$ increases, $\beta$ will increase from 0 to $56.29 \%$. Compared with the case where the $P_{t}^{L}$ is less than 0.5 , when $P_{t}^{L}$ is greater than 0.5 , as $\gamma$ increases, $\beta$ increases faster, and the magnitude of the increase is greater. When both $P_{t}^{L}$ and $\gamma$ are at a maximum, $\beta$ is the highest. Thus, when the land marginal return of the enterprises entering the market is high, the optimal proportion of stock capital in land increment income increases faster and more compared to the situation where the land marginal return in the enterprises entering the market is lower with the increase of the enterprise's profit margin.

Figure $5 \mathrm{~b}$ shows the relationship between the expected return rate of the stock capital and OPPSC when the wage changes. If $W_{t}$ is lower than 0.5 , as $\gamma$ increases, $\beta$ will increase from 0 to $64.08 \%$; if $W_{t}$ is higher than 0.5 , as $\gamma$ increases, $\beta$ will increase from 0 and $48.5 \%$, which is slower and less than when $W_{t}$ is lower than 0.5 . Therefore, when an area is more developed, OPPSC increases less and slower than in the less-developed area with the enterprise's profit margin increases.

Figure 6a shows the relationship between the expected return rate of the stock capital and OPPSC when the proportion of land increment income in land transfer fee changes. As $\gamma$ and $\omega$ change, $\beta$ varies between $0 \%$ and $61.09 \%$. When $\omega$ is less than $0.5, \beta$ increases from 0 to $58.1 \%$ with an increase of $\gamma$; when $\omega$ is higher than $0.5, \beta$ increases from 0 to $61.09 \%$ with an increase of $\gamma$. When $\omega$ is larger, $\beta$ increases more than when $\omega$ is smaller as $\gamma$ increases. Hence, when the developing cost of RCOCL entering the market is lower, with the enterprise's profit margin increases, OPPSC increases more and faster than the RCOCL with the higher developing cost.

Figure $6 \mathrm{~b}$ shows the relationship between the expected return rate of the stock capital and OPPSC when the marginal utility elasticity of the lump-sum currency payment changes. Under this premise, as $\gamma$ and $b$ change, $\beta$ fluctuates in the range of $0-99.99 \%$. When $b$ is smallest and $\gamma$ is the largest, $\beta$ is the largest. If $b$ is less than 1 , as $\gamma$ increases, $\beta$ will increase from 0 to $99.99 \%$; if $1<b<2$, as $\gamma$ increases, $\beta$ will increase from 0 to $56 \%$, and it increases by a smaller proportion. This means that when farmers' marginal utility elasticity of the lump-sum payment is low, with an increase of profit margin of enterprise entering the market, OPPSC increases more and faster than the case when farmers' marginal utility elasticity of the lump-sum payment is higher.

\subsubsection{Farmers' Heterogeneity and OPPSC}

Figure 7 shows that the marginal utility elasticity of the lump-sum currency payment and OPPSC is negatively correlated. 


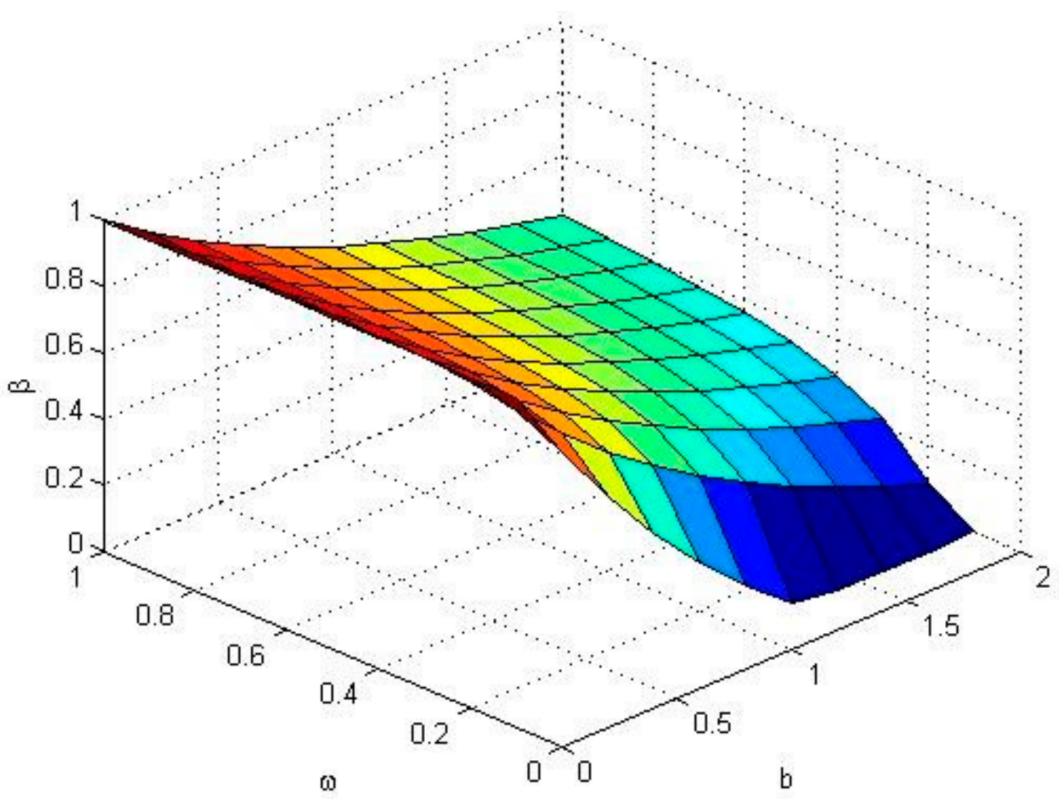

Figure 7. Farmers' heterogeneity and OPPSC.

Figure $4 \mathrm{~d}$ shows the relationship between the marginal utility elasticity of the lumpsum currency payment and OPPSC when the land transfer price changes. When $P_{t}^{L}$ is lower than $0.5, \beta$ is between 0 and $99.99 \%$ at any $b$; when $P_{t}^{L}$ is higher than $0.5, \beta$ is between $6.59 \%$ and $99.99 \%$ at any $b$. When $P_{t}^{L}$ is less than 0.5 , as $b$ increases, $\beta$ decreases more and faster than when $P_{t}^{L}$ is higher than 0.5 . That is, when the land marginal return of enterprises entering the market is relatively low, with an increase of the local farmers' marginal utility elasticity of a lump-sum payment, OPPSC decreases more and faster than the case when the land marginal return of enterprises entering the market is relatively low.

Figure $5 \mathrm{c}$ also exhibits the relationship between the marginal utility elasticity of the lump-sum currency payment and OPPSC when the wage changes. When $W_{t}$ is lower than $0.5, \beta$ is between $6.59 \%$ and $99.99 \%$ with $b$ increases; when $W_{t}$ is higher than 0.5 , as $b$ increases, $\beta$ is between 0 and $99.99 \%$. Compared to the situation where $W_{t}$ is less than 0.5 , when $W_{t}$ is higher than $0.5, \beta$ decreases at a faster rate as $b$ increases. Thus, when the regional economic development level is high, OPPSC decreases faster compared to the situation when the marginal utility elasticity of the lump-sum currency payment is lower as the marginal utility elasticity of the lump-sum payment of farmers increases.

Figure $6 \mathrm{~b}$ also shows the relationship between the marginal utility elasticity of the lump-sum currency payment and OPPSC when the expected return rate of the stock capital changes. If $\gamma$ is lower than 20 , with the increase of $b, \beta$ will decrease from $99.99 \%$ to 0 ; if $\gamma$ is higher than 20 , with the increase of $b, \beta$ will decrease from $99.99 \%$ to $6.19 \%$. When $\gamma$ is lower than 20, $\beta$ decreases faster than the case where $\gamma$ is higher than 20 with $b$ increases. That is, when an enterprise's profit margin is relatively high, OPPSC decreases slower and less than when the enterprise's profit margin is lower with the increase of farmers' marginal utility elasticity of the lump-sum currency payment.

Figure 7 shows the relationship between the marginal utility elasticity of the lumpsum currency payment and OPPSC when the proportion of land increment income in land transfer fee changes. If $\omega$ is lower than 0.5 , as $b$ increases, $\beta$ will decrease from $99.99 \%$ to 0 ; if $\omega$ is higher than 0.5 , as $b$ increases, $\beta$ will decrease from $99.99 \%$ to $33.54 \%$. When $\omega$ is less than $0.5, \beta$ decreases faster than when $\omega$ is higher than 0.5 as $b$ increases. Therefore, when the development cost of RCOCL entering the market is low, OPPSC decreases faster and more than when the development cost of RCOCL entering the market is higher with an increase of local farmers' marginal utility elasticity of the lump-sum currency payment. 


\subsection{Scenario Analysis}

To show clearly what the optimal distribution ratio of pension or stock capital in land increment income should be under different conditions, we simulated eight typical scenarios based on the actual situation for China's RCOCL entering the market. $P_{t}^{L}$ and $W_{t}$ are set at increasing values, indicating the five areas where the economic development level is improving; $\gamma$ is set to 20.16 or a value higher. When $\gamma$ is equal to 20.16 , it indicates that the farmers choose the payment mode that includes pension; when $\gamma$ is higher than 20.16, it indicates that the farmers choose the payment mode that includes dividends. Different $\omega$ means that the development cost of RCOCL varies. Under normal circumstances, the land development cost of underdeveloped areas will be higher than that of developed areas. This is because compared with developed areas, RCOCL in underdeveloped areas entering the market requires more investment in land consolidation and local infrastructure construction [56]. In general, compared with developed areas, farmers in less developed areas are more inclined to obtain stable and guaranteed income. Therefore, the same lumpsum income will bring less utility to farmers in underdeveloped areas than in developed areas [57]. Then, $b$ in developed regions is set higher than the median value, and $b$ in underdeveloped regions is set lower than the median value.

Table 4 shows OPPSC under different conditions of RCOCL entering the market. OPPSC fluctuates from $50 \%$ to $70 \%$ in most cases. Generally, OPPSC of regions with lower economic development levels is higher than that of regions with higher economic development levels. However, there are also cases where OPPSC of the economically worse areas is lower than that of the more developed areas, for example, Scenario III and Scenario VIII. Compared with Scenario III, the area represented by Scenario VIII is more developed, the development cost of this RCOCL is lower, and local farmers are more willing to receive monetary income, but deferred payment of a higher proportion of land increment income can allow farmers to gain more utility. This also shows that when determining OPPSC, the influence of multiple factors on this proportion should be considered.

Table 4. OPPSC in different scenarios.

\begin{tabular}{cccccccccc}
\hline Scenario & I & II & III & IV & V & VI & VII & VIII & IX \\
\hline$P_{t}^{L}$ & 0.1 & 0.3 & 0.5 & 0.5 & 0.5 & 0.7 & 0.7 & 0.9 & 0.9 \\
$W_{t}$ & 0.1 & 0.3 & 0.5 & 0.5 & 0.5 & 0.7 & 0.7 & 0.9 & 0.9 \\
$\gamma$ & 20.16 & 20.16 & 20.16 & 26 & 32 & 20.16 & 26 & 32 & 38 \\
$\omega$ & 0.2 & 0.8 & 0.5 & 0.4 & 0.7 & 0.8 & 0.5 & 0.8 & 0.5 \\
$b$ & 0.5 & 0.8 & 1 & 0.8 & 1.2 & 1.2 & 1.5 & 1.2 & 1.5 \\
$\beta$ & $65.23 \%$ & $66.91 \%$ & $57 \%$ & $64.35 \%$ & $59.29 \%$ & $55.89 \%$ & $47.88 \%$ & $59.98 \%$ & $52.29 \%$ \\
\hline
\end{tabular}

\section{Discussion}

China is going through a stage of deepening the reform of the rural land system [26]. In this reform, China has introduced a series of reform measures to relax rural land property rights and strengthen farmers' land development rights [3]. RCOCL entering the market is an important part of these reform measures $[26,27]$. The Chinese government hopes to gradually establish a unified urban and rural land market, promote the flow of production factors, and narrow the gap between urban and rural areas through RCOCL entering the market. In addition, the protection of the income of village collectives and farmers is not only the requirement of the Chinese government for RCOCL entering the market but also the internal driving force to ensure the smooth operation of this reform [58]. The choice of payment mode for farmers' increment income when RCOCL enters the market will affect farmers' long-term income. Therefore, it has also become one of the key factors that determine whether the reform of RCOCL entering the market can run smoothly.

Similar to the results of previous studies, we find that the determination of the payment plan needs to consider the heterogeneity of farmers and the use of land, and diversified payment forms can bring more utility to farmers [59-63]. Different from existing studies, we find that mixed payment modes are not optimal in all situations. If the land 
transfer price is lower than a specific value, the lump-sum currency payment can bring greater utility to farmers than mixed payment. In this case, the lump-sum currency payment is optimal for farmers. Moreover, the existing researchers do not discuss the question of what proportions should be allocated for different forms of payment when the compensation is fixed. Therefore, compared with the existing research, we further discussed the proportion of cash and other forms of payment that should be allocated when the compensation includes cash, shareholding, and pensions, which provides a supplement to the research on payment of land rights transfer.

The results show that not only the total amount of currency paid to farmers' will affect their willingness to participate in the transfer of land rights, but also the payment mode will also affect the willingness by affecting farmers' long-term utility. This indicates that China's policy of mainly using lump-sum currency payments when giving farmers compensation needs to be improved in the marketization of rural land. The compensation payment mode should be optimized based on the perspective of maximizing the long-term utility of farmers, so as to achieve the goal of promoting the marketization reform of rural land. The results further show that optimizing the payment mode for farmers' land rights transfer compensation should take full account of key factors such as regional economic differences and industry differences among land-using enterprises. Based on the results, we make the following policy suggestions.

First, develop compensation payment schemes with regional differences. The results show that when farmers' compensation is fixed, in economically developed areas, the proportion of lump-sum currency in land increment income should be appropriately increased, while in economically underdeveloped areas, the proportion of it should be moderately reduced, which can improve the farmers' long-term utility to a certain extent. This may be because compared with underdeveloped areas, farmers in developed areas have more diversified ways to maintain their livelihoods, and farmers' reliance on agriculture is relatively lower. Farmers in developed areas tend to worry less about their future livelihoods, and they prefer to receive cash compensation in the short term for investment or entrepreneurship. Therefore, the central government can formulate different farmers' land increment income payment plans for RCOCL entering the market based on the regional economic development level.

Second, formulate industry guidelines to provide references for farmers' compensation payment modes in different situations. For different land-use enterprises, their profit margins are different. This determines that different enterprises participating in the market will have different OPPSCs. Specifically, for enterprises with higher profit margins, the proportion of lump-sum currency in land increment income should be moderately reduced; for enterprises with lower profit margins, the proportion of lump-sum currency in land increment income should be moderately increased. Therefore, local governments can formulate industry guidelines to provide references for farmers' compensation payment modes in different situations. When the profit margins of enterprises participating in the market are high, such as real estate and tourism, a stock capital-based payment mode is adopted. However, it should be noted that industries with higher profit margins are often more susceptible to uncertainties, and future earnings have greater uncertainty and instability. When the proportion of stock capital in the land increment income is as high as $80 \%$ or more, farmers can be guided to appropriately reduce the shareholding allocation ratio and choose a more stable form of payment. When the profit margins of the enterprises participating in the market are low, a cash payment-based payment mode is adopted.

Third, farmers should be provided with diversified and alternative compensation schemes. The results show that farmers under different backgrounds have different preferences for payment modes. Therefore, in addition to considering the above factors, the determination of OPPSC should also fully consider the heterogeneity of farmers and fully understand farmers' different demands for compensation. Thus, in order to understand the needs of farmers, the government should increase public participation when formulating compensation payment plans. In the specific implementation methods, each region incor- 
porates farmers' willingness to pay for compensation into the pre-investigation content, extensively listens to farmers' requirements and suggestions on compensation, respects farmers' wishes, and concentrates on farmers' opinions and suggestions. In addition, an information-sharing mechanism should also be established. As the administrative body, the government should avoid top-down compulsory instructions. Before and after the compensation payment plan is determined, it should adopt multiple channels such as the Internet, announcements, consultations, or windows to establish an information sharing mechanism with farmers and give farmers the right to know.

The essence of RCOCL entering the market is the transfer of land rights and interests. In this process, land use rights are transferred from farmers to land use enterprises, and farmers receive a certain amount of compensation through it. In fact, land acquisition, land fallowing, and ecological protection programs are also the conversion of rights and interests. In land acquisition, land ownership is transferred from the land owner (farmer or village collective) to the government, and the land owner receives a certain amount of compensation for land acquisition; in land fallowing, including the US's Conservation Reserve Program (CRP), EU's Common Agricultural Policy (CAP), Japan's agricultural land fallow plan, and China's fallow policy, farmers' land income rights are weakened, part of their land income rights are transformed into positive externalities of the environment, and farmers receive subsidies for participating in land fallowing. Therefore, the optimal payment mode selection model can provide a reference for the determining of the payment mode in the process of land rights transfer, such as land acquisition and land leasing. In addition, this study provides a framework for the study on the optimal payment for ecosystem services program, such as land fallowing.

This study also has some limitations. How do we estimate these important parameters for a specific country or region? We provide a theoretical framework for determining the optimal payment mode for compensation. However, for a particular country or region, the payment mode that should be selected and the empirical analysis that must be carried out are important parameters that must be carefully estimated. If the estimation is not carried out or the estimation is inaccurate, no correct conclusion can be drawn. In addition, the study discusses the three most typical payment modes to farmers in the process of rural land rights transfer in China. However, in practice, more payment modes have been derived, including the mixed mode of currency payment and employment, and the mixed mode of currency payment and technical training $[41,64,65]$.

In future studies, we will incorporate more payment modes derived from the practice process into the theoretical analysis framework to find the optimal solutions to deal with complex situations. Furthermore, RCOCL entering the market is a newly introduced rural land reform system in China in 2019. There is still relatively little practical experience and data. It is still difficult to test the rigor of the optimal payment mode selection model constructed in this study with empirical research. In future research, it is necessary to collect empirical data and verify the rigor of the model.

\section{Conclusions}

This study constructs an optimal payment mode selection model of land increment income of RCOCL entering the market based on farmers' lifetime utility maximization, and it analyzes the influence of factors such as land transfer price, land development cost, the marginal utility elasticity of the lump-sum currency payment of farmers, and enterprises' profit margin on the optimal payment mode. Then, it calculates the optimal payment mode selection under different RCOCL transfer prices. Furthermore, based on actual data and existing research results, it determines OPPSC under two typical mixed payment modes. This paper provides a decision-making plan for how to determine the optimal payment mode of compensation in the process of land rights transfer, such as land acquisition and land leasing, under certain conditions of compensation that farmers deserve. In addition, it incorporates the utility of different payment modes for farmers into the intertemporal utility model, which can provide a reference for determining the optimal allocation of 
different payment methods when the payment of ecological service program, such as land fallowing, is fixed. The main conclusions are as follows.

First, there are three typical payment modes of land increment income obtained by farmers in the process of RCOCL entering the market. In different situations of RCOCL entering the market, the optimal payment mode that can maximize farmers' utility should be different. Specifically, if the land transfer price of RCOCL is lower than a specific value determined by related factors, the lump-sum currency payment will be the optimal payment mode for this kind of RCOCL entering the market; if it is higher than this specific value, the mixed payment of pension or dividend and lump-sum currency will be the optimal payment mode. If the enterprise's profit margin is higher than the pension rate of return, the mixed payment of dividends and lump-sum currency will be optimal; if it is lower than the pension rate of return, the mixed payment of pensions and lump-sum currency will be optimal.

Second, OPPSC is determined by the marginal utility elasticity of the lump-sum currency payment of local farmers, the marginal utility elasticity of consumption, the proportion of land increment income in land transfer fees, the deposit interest rate, the pension rate of return, and the land transfer area. This means that the economic development level of the areas where RCOCL enters the market, the attributes of enterprises participating in the marketization of RCOCL, and the characteristics of local farmers will differentiate OPPSC. When choosing a mixed payment of pension or dividend and lump-sum currency payment, the optimal proportion of lump-sum currency payment in increment income is often between $40 \%$ and $60 \%$.

Author Contributions: Conceptualization, L.Y., H.L. and K.H.; methodology, L.Y. and H.L.; validation, L.Y., H.L. and K.H.; formal analysis, L.Y. and H.L.; data curation, H.L.; writing-original draft preparation, L.Y.; writing-review and editing, L.Y., H.L. and K.H.; visualization, L.Y. and H.L; supervision, K.H.; funding acquisition, K.H. All authors have read and agreed to the published version of the manuscript.

Funding: This study is supported by the National Social Science Foundation of China (No.18CJY033), the Provincial Social Science Foundation of Hunan (No.18YBQ132) and the Soft Science Research Program of Zhejiang Province (No.2021C35060).

Institutional Review Board Statement: Not applicable.

Informed Consent Statement: Not applicable.

Data Availability Statement: The data of the three cases can be found in the following websites: http:/ / www.stats.gov.cn/tjsj/ndsj/2020/indexch.htm, http:/ / www.gov.cn/xinwen/2017-03/29 / content_5181637.htm, (accessed on 29 March 2017), http:/ / www.ce.cn/macro/more/201810/23/t2 0181023_30601945.shtml, (accessed on 23 October 2018), http:/ / www.ceweekly.cn/2020/1211/3243 12.shtml, (accessed on 11 December 2020).

Acknowledgments: The authors are grateful to Kunqiu Chen for his guidance on the research. We also thank all the interviewees in the field visits.

Conflicts of Interest: The authors declare no conflict of interest.

\section{References}

1. Chen, K.Q.; Long, H.L.; Ma, L.; Zhang, Y.N. China's rural land reform and rural vitalization. Prog. Geogr. 2019, 38, 1424-1434. (In Chinese) [CrossRef]

2. Chen, K.; Long, H.; Liao, L.; Tu, S.; Li, T. Land use transitions and urban-rural integrated development: Theoretical framework and China's evidence. Land Use Policy 2020, 92, 104465. [CrossRef]

3. Liu, Y.S.; Li, Y.H. Revitalize the world's countryside. Nature 2017, 548, 275-277. [CrossRef] [PubMed]

4. Yep, R.; Forrest, R. Elevating the peasants into high-rise apartments: The land bill system in Chongqing as a solution for land conflicts in China? J. Rural Stud. 2016, 47, 474-484. [CrossRef]

5. Lichtenberg, E.; Ding, C. Local officials as land developers: Urban spatial expansion in China. J. Urban Econ. 2009, 66, 57-64. [CrossRef]

6. He, C.F.; Huang, Z.J.; Wang, R. Land use change and economic growth in urban China: A structural equation analysis. Urban Stud. 2014, 51, 2880-2898. [CrossRef] 
7. Long, H.L.; Liu, Y.S.; Li, X.; Chen, Y. Building new countryside in China: A geographical perspective. Land Use Policy 2010, 27, 457-470. [CrossRef]

8. Huang, D.; Lang, Y.; Liu, T. The evolving structure of rural construction land in rrbanizing China: Case study of Tai'an prefecture. Land 2021, 10, 65. [CrossRef]

9. Hong, K.R.; Zou, Y.C.; Zhu, M.Y.; Zhang, Y.W. A game analysis of farmland expropriation conflict in China under multidimensional preference: Cooperation or resistance? Land 2021, 10, 124. [CrossRef]

10. Wen, L.J.; Butsic, V.; Stapp, J.R.; Zhang, A.L. What happens to land price when a rural construction land market legally opens in China? A spatiotemporal analysis of Nanhai district from 2010 to 2015. China Econ. Rev. 2020, 62, 101197. [CrossRef]

11. Liu, H.; Zhou, Y. The marketization of rural collective construction land in northeastern China: The mechanism exploration. Sustainability 2020, 13, 276. [CrossRef]

12. Wang, H.; Zhang, X.; Wang, H.; Skitmore, M. The right-of-use transfer mechanism of collective construction land in new urban districts in China: The case of Zhoushan City. Habitat Int. 2017, 61, 55-63. [CrossRef]

13. General Office of the CPC Central Committee and the State Council. Opinions on the Pilot Work of Rural Land Expropriation, Collectively-Owned Operating Construction Land Entering the Market, and Homestead System Reform. Available online: http:/ / www.whncfp.gov.cn/art/2016/3/21/art_42552_1250207.html (accessed on 21 March 2016).

14. Chinese Ministry of Finance, China Ministry of Land and Resources. Interim Measures for the Administration of the Collection and Use of the Adjustment Fund for the Increment Income of rural Collectively-Owned Operating Construction Land. Available online: http:/ / www.gov.cn/xinwen/2016-06/13/content_5081507.htm (accessed on 18 April 2016).

15. He, F.; Long, J.G.; Fan, H.; Zhou, M.L. The balanced value distribution among state, collectives and farmers: A study on adjustment funds of collective construction land transaction. Issues Agric. Econ. 2019. (In Chinese) [CrossRef]

16. Wang, M.; Zhu, P.; Zhang, Z. Study on collective construction land transfer revenue sharing mechanism: Take Kunshan City for example. China Land Sci. 2016, 30, 51-57. (In Chinese) [CrossRef]

17. Yan, L.; Hong, K.R.; Chen, K.Q.; Li, H.; Liao, L.W. Benefit distribution of collectively-owned operating construction land entering the market in rural China: A multiple principal-agent theory-based analysis. Habitat Int. 2021, 109, 102328. [CrossRef]

18. Fennell, L.A. Taking eminent domain apart. Mich. State Law Rev. 2004, 2004, 957-1004.

19. Niemann, P.; Shapiro, P. Efficiency and fairness: Compensation for takings. Int. Rev. Law Econ. 2008, 28, 157-165. [CrossRef]

20. Lehavi, A.; Licht, A.N. Squaring the eminent domain circle: A new approach to land assembly problems. Land Lines 2007, $19,14-19$.

21. Siebert, R.; Berger, G.; Lorenz, J.; Pfeffer, H. Assessing German farmers' attitudes regarding nature conservation set-aside in regions dominated by arable farming. J. Nat. Conserv. 2010, 18, 327-337. [CrossRef]

22. Duesberg, S.; Dhubháin, Á.N.; O'Connor, D. Assessing policy tools for encouraging farm afforestation in Ireland. Land Use Policy 2014, 38, 194-203. [CrossRef]

23. Barnes, A.; Sutherlandb, L.; Tomaa, L.; Matthews, K.; Thomsona, S. The effect of the Common Agricultural Policy reforms on intentions towards food production: Evidence from livestock farmers. Land Use Policy 2016, 50, 548-558. [CrossRef]

24. Quirogaa, S.; Cristina, S.; Zaira, F.; George, P. Levelling the playing field for European Union agriculture: Does the Common Agricultural Policy impact homogeneously on farm productivity and efficiency? Land Use Policy 2017, 68, 179-188. [CrossRef]

25. Reimer, A. Ecological modernization in U.S. agri-environmental programs: Trends in the 2014 Farm Bill. Land Use Policy 2015, 47, 209-217. [CrossRef]

26. Zhou, Y.; Li, X.H.; Liu, Y.S. Rural land system reforms in China: History, issues, measures and prospects. Land Use Policy 2020, 91, 104330. [CrossRef]

27. Zhou, C.; Liang, Y.; Fuller, A. Tracing agricultural land transfer in China: Some legal and policy issues. Land 2021, 10, 58. [CrossRef]

28. Kuusaana, E.D.; Eledi, J.A. As the city grows, where do the farmers go? Understanding peri-urbanization and food systems in Ghana-Evidence from the Tamale Metropolis. Urban Forum 2015, 26, 443-465. [CrossRef]

29. Huang, H.; Zhou, Y.; Qian, M.; Zeng, Z. Land use transition and driving forces in Chinese Loess Plateau: A case study from Pu County, Shanxi Province. Land 2021, 10, 67. [CrossRef]

30. Wadduwage, S.; Millington, A.; Crossman, N.D.; Sandhu, H. Agricultural land fragmentation at urban fringes: An application of urban-to-rural gradient analysis in Adelaide. Land 2017, 6, 28. [CrossRef]

31. Wang, L.J.; Li, H.; Shi, C. Urban land-use efficiency, spatial spillover, and determinants in China. Acta Geogr. Sin. 2015, 70, 1788-1799. (In Chinese)

32. Zhang, F.T. Let the reform of "Separation of three powers" of homestead become a new grasp for vitalization of rural areas. People's Trib. 2018, 10, 75-77.

33. The State Council's summary report on rural land expropriation, collectively-owned operating construction land entering the market, and the pilot reform of the homestead system. Commun. Standing Comm. Chin. People's Congr. 2019, 1, $292-296$.

34. Cai, Y.; Yu, L. Rural household participation in and satisfaction with compensation programs targeting farmland preservation in China. J. Clean. Prod. 2018, 205, 1148-1161. [CrossRef]

35. Hayakawa, K. The non-neutrality of money and the optimal monetary growth rule when preferences are recursive: Cash-inadvance vs. money in the utility function. J. Macroecon. 1992, 14, 233-266. [CrossRef] 
36. Yu, N.; Shi, Q.H.; Jin, H.T. Permanent land-use rights and endowment insurance: Chinese evidence of the substitution effect. China Econ. Rev. 2010, 21, 272-281. [CrossRef]

37. Bremer, L.L.; Farley, K.A.; Lopez-Carr, D. What factors influence participation in payment for ecosystem services programs? An evaluation of Ecuador's SocioPáramo program. Land Use Policy 2014, 36, 122-133. [CrossRef]

38. Hansen, K.; Duke, E.; Bond, C.; Purcell, M.; Paige, G. Rancher preferences for a payment for ecosystem services program in Southwestern Wyoming. Ecol. Econ. 2018, 146, 240-249. [CrossRef]

39. Home, R.; Balmer, O.; Jahrl, I.; Stolze, M.; Pfiffner, L. Motivations for implementation of ecological compensation areas on Swiss lowland farms. J. Rural Stud. 2014, 34, 26-36. [CrossRef]

40. Cao, Y.; Dallimer, M.; Stringer, L.C.; Bai, Z.; Siu, Y.L. Land expropriation compensation among multiple stakeholders in a mining area: Explaining "skeleton house" compensation. Land Use Policy 2018, 74, 97-110. [CrossRef]

41. Qian, Z. Land acquisition compensation in post-reform China: Evolution, structure and challenges in Hangzhou. Land Use Policy 2015, 46, 250-257. [CrossRef]

42. Kaczan, D.; Swallow, B.M.; Adamowicz, W.L. Designing a payments for ecosystem services (PES) program to reduce deforestation in Tanzania: An assessment of payment approaches. Ecol. Econ. 2013, 95, 20-30. [CrossRef]

43. Hao, Y. Farmland is alive, industry is on fire. People's Daily, 29 March 2017; 10.

44. Liu, C.; Du, S. Zhanqi Village, Tangchang Street, Pidu District, Chengdu, Sichuan, "Land Market” activates industrial development. Economic Daily, 23 October 2018; 15.

45. Wang, M. Taizhou's First Pilot Project: The Signing of a Contract for Collectively-Owned Operating Construction Land in Dongluo Village. 2020. Available online: http:/ / www.ceweekly.cn/2020/1211/324312.shtml (accessed on 11 December 2020).

46. Evans, D.J. The elasticity of marginal utility of consumption: Estimates for 20 OECD Countries. Fiacal Stud. 2005, 26, 197-224. [CrossRef]

47. Layard, R.; Mayraz, G.; Nickell, S. The marginal utility of income. J. Public Econ. 2008, 92, 1846-1857. [CrossRef]

48. Ding, C.R.; Lichtenberg, E. Land and urban economic growth in China. J. Reg. Sci. 2011, 51, 299-317. [CrossRef]

49. Gui, F.A.; Fodder, J.; Shahriar, A.Z.M. Performance of microfinance institutions: Does government ideology matter? World Dev. 2017, 100, 1-15. [CrossRef]

50. Aryeetey, E.; Baah-Nuakoh, A.; Duggleby, T.; Hettige, H.; Steel, W.F. Supply and Demand for Finance of Small Entreprises in Ghana; World Bank-Discussion Papers; World Bank: Washington, DC, USA, 1994; pp. 172-180.

51. Hansen, G.S.; Wernerfelt, B. Determinants of firm performance: The relative importance of economic and organizational factors. Strateg. Manag. J. 1989, 10, 399-411. [CrossRef]

52. Zhang, J.; Huang, T.; Lu, Z. Study on the determine mechanism of the source and difference of Chinese enterprises' profit. China Ind. Econ. 2011, 1, 27-37. (In Chinese) [CrossRef]

53. Dixit, A.K.; Wu, G.; Feng, Q. Optimization in Economic Theory; Shanghai People's Publishing House: Shanghai, China, 2013.

54. Machina, M.J. Choice Under Uncertainty: Problems Solved and Unsolved. J. Econ. Perspect. 1987, 1, 121-154. [CrossRef]

55. Lans Bovenberg, A.; Smulders, S. Environmental quality and pollution-augmenting technological change in a two-sector endogenous growth model. J. Public Econ. 1995, 57, 369-391. [CrossRef]

56. Hirschman, A.O. Investment policies and "Dualism" in underdeveloped countries. Am. Econ. Rev. 1957, 47, 550-570.

57. Zhang, X.; Xu, Z. Functional coupling degree and human activity intensity of production-living-ecological space in underdeveloped regions in China: Case study of Guizhou Province. Land 2021, 10, 56. [CrossRef]

58. Irawan, S.; Tacconi, L.; Ring, I. Stakeholders' incentives for land-use change and REDD+: The case of Indonesia. Ecol. Econ. 2013, 87, 75-83. [CrossRef]

59. Ranjan, R. Payments for ecosystems services-based agroforestry and groundwater nitrate remediation: The case of Poplar deltoides in Uttar Pradesh, India. J. Clean. Prod. 2021, 287, 15. [CrossRef]

60. Banerjee, P.; Pal, R.; Wossink, A.; Asher, J. Heterogeneity in farmers' social preferences and the design of green payment schemes. Environ. Resour. Econ. 2021, 78, 201-226. [CrossRef]

61. Broch, S.W.; Vedel, S.E. Using choice experiments to investigate the policy relevance of heterogeneity in farmer agri-environmental contract preferences. Environ. Resour. Econ. 2012, 51, 561-581. [CrossRef]

62. Cao, Z.Y.; Zou, Y.C.; Zhao, X.; Hong, K.R.; Zhang, Y.W. Multidimensional fairness equilibrium evaluation of urban housing expropriation compensation based on VIKOR. Mathematics 2021, 9, 430. [CrossRef]

63. Krishna, V.V.; Drucker, A.G.; Pascual, U.; Raghu, P.T.; King, E. Estimating compensation payments for on-farm conservation of agricultural biodiversity in developing countries. Ecol. Econ. 2013, 87, 110-123. [CrossRef]

64. Patil, V.; Ghosh, R.; Kathuria, V.; Farrell, K.N. Money, Land or self-employment? Understanding preference heterogeneity in landowners' choices for compensation under land acquisition in India. Land Use Policy 2020, 97, 16. [CrossRef]

65. Reimer, A.P.; Prokopy, L.S. Farmer participation in U.S. Farm Bill Conservation Programs. Environ. Manag. 2014, 53, 318-332. [CrossRef] 